(C) The Author(s) 2020. Published by Cambridge University Press. This is an Open Access article, distributed under the terms of the Creative Commons Attribution licence (http://creativecommons.org/ licenses/by/4.0/), which permits unrestricted re-use, distribution, and reproduction in any medium, provided the original work is properly cited.

\title{
EQUAL TREATMENT OF PARTIES IN INTERNATIONAL COMMERCIAL ARBITRATION
}

\author{
ILIAS BANTEKAS* (10
}

\begin{abstract}
Although fair trial guarantees have always been recognised as constituting an integral aspect of international arbitral proceedings, this has largely been viewed through the lens of civil procedure rather than as a matter of public law and human rights. This state of affairs has further been compounded by the confidential nature of arbitration and the relative scarcity of set aside (annulment) proceedings before the courts of the seat of arbitration on the grounds of unequal treatment, and before human rights bodies such as the European Court of Human Rights. Moreover, it has always been difficult to reconcile contractual freedom and the advantages offered by arbitration with equal treatment and fair trial claims. This article demonstrates the existence of a set of general principles concerning the meaning and content of equal treatment, which are consistent with its commercial (and civil procedure) and human rights dimensions. The basis of this conclusion is Article 18 of the UNCITRAL Model Law on International Commercial Arbitration, as consistently interpreted and adapted by local laws and judgments, arbitral statutes and determinations by the European Court of Human Rights.
\end{abstract}

Keywords: private international law, fair trial, rights in private sphere, equal treatment, set aside proceedings, international commercial arbitration.

\section{INTRODUCTION}

The identification of important linkages between trade, commerce and investment and human rights is relatively recent. Although the majority of the literature has, for good reason, focused on the impact of international trade and foreign investment on socio-economic rights, ${ }^{1}$ little attention has been paid to the interaction between private law and civil and political rights. For a long time it was assumed that arbitration was in little need of fair trial

* Professor of International Law, Hamad bin Khalifa University (Qatar Foundation), College of Law and Adjunct Professor of Law, Georgetown University, Edmund A Walsh School of Foreign Service, ibantekas@hbku.edu.qa. Open Access funding provided by the Qatar National Library.

${ }^{1}$ See P-M Dupuy, F Francioni and E-U Petersmann (eds), Human Rights in International Investment Law and Arbitration (Oxford University Press 2009); P Alston and N Reisch (eds), Taxation, Inequality and Human Rights (Oxford University Press 2019); H Hestermeyer, Human Rights and the WTO: The Case of Patents and Access to Medicines (Oxford University Press 2008). 
guarantees because commercial actors were protective of their confidentiality and that in any event arbitral proceedings did not give rise to such concerns. The absence of a public record of the proceedings as a result of their confidential nature provided the mistaken impression that somehow the parties had contracted out of fair trial guarantees. However, with the proliferation of arbitration not only in the transnational business community but also in respect of a vast range of domestic proceedings, from commercial to employment disputes, the legal landscape has changed considerably. Major commercial arbitration instruments give a prominent place to fair trial rights, as is the case with Article 18 of the UN Commission on International Trade Law (UNCITRAL) Model Law on International Commercial Arbitration, ${ }^{2}$ which reads that:

The parties shall be treated with equality and each party shall be given a full opportunity of presenting his case. ${ }^{3}$

Given that arbitration constitutes a permissible exception to the authority of the civil and commercial courts, which are naturally subject to fair trial guarantees, it is imperative that arbitral tribunals are equally bound to adhere to such guarantees. What is the theoretical legal basis for subjecting both regular courts and arbitral tribunals to the same fair trial legal framework? Despite the autonomy and 'international' character of international arbitration, two justifications have generally been posited to demonstrate that arbitral proceedings are but a mere component of the law and legal system of the seat of arbitration and, by extension, that the arbitrator is an organ dispensing that law.

Both the objectivist ${ }^{4}$ and the subjectivist ${ }^{5}$ views take the position that arbitral tribunals dispense the law of the seat of arbitration in the same manner as its domestic courts and that the freedom to choose substantive and procedural rules, an otherwise inherent feature of arbitration, is always subject to its compatibility with the lex arbitri. In this sense, the lex arbitri is equivalent to

\footnotetext{
2 The Model Law was negotiated and drafted at intergovernmental level just like a treaty, but it is not a treaty nor does it have binding force. The objective of UNCITRAL was that it be adopted by as many States as possible, subject to domestic legal particularities, with a view to global uniformity. Countries adopting and consistently implementing the Model Law are considered arbitration friendly, even if they are not major arbitration seats. See I Bantekas, 'Article 2A' in I Bantekas, P Ortolani et al., UNCITRAL Model Law on International Commercial Arbitration: Commentary (Cambridge University Press 2020) 38-49.

3 There are, of course, several other fair trial guarantees that are pertinent to arbitration, but they are beyond the scope of this article. Chief among these is the proper notification of parties. For an extensive discussion, see I Bantekas, 'Article 3', ibid, 50-70.

${ }^{4}$ As chiefly expressed by FA Mann, 'The UNCITRAL Model Law: Lex Facit Arbitrum' (1986) 2 ArbIntl 241; as endorsed, among others, by WW Park, 'The Lex Loci Arbitri in International Commercial Arbitration' (1983) 32 ICLQ 21, 22. The opposite view of detached arbitrations generally finds little support, but see J Paulsson, 'Arbitration Unbound: Award Detached from the Law of its Country of Origin' (1981) 30 ICLQ 358.

5 R Goode, 'The Role of the Lex Loci Arbitri in International Commercial Arbitration' (2001) 17 ArbIntl 19.
} 
the lex fori in civil proceedings. ${ }^{6}$ The freedom to choose and enforce substantive and procedural rules exists only because the law of the seat of arbitration views the rules chosen or rejected through a permissive lens. By extension, the human rights laws of the seat of arbitration, which includes incorporated treaties and obligations stemming from them, are binding on arbitral tribunals because they are an integral part of the lex arbitri and cannot be waived by consent of the parties or by virtue of the tribunals' inherent or other powers.

Again, by implication, deviations from the human rights laws of the seat of arbitration are permissible only to the degree that this is permitted by the rule itself (ie it is a permissive rule). This might be as a result of a judgment of a domestic or international court, or as a result of legislation. That the mandatory/peremptory laws of the seat of arbitration are binding on the parties and tribunals is also evident from the fact that arbitration agreements may not circumvent mandatory EU legislation. This outcome was confirmed by the English High Court in relation to the EU Commercial Agents Directive. ${ }^{7}$ In Accentuate Ltd $v$ Asigra Inc ${ }^{8}$ the English High Court held that the parties could not circumvent the indemnity and compensation provisions of the Directive and any award that was in breach of these mandatory provisions would be refused on grounds of public policy.

Having considered the legal basis as to why mandatory fair trial guarantees supersede contractual autonomy, it should be stressed that from a fair trial perspective fairness aims to secure the interests of the parties and the proper administration of justice. ${ }^{9}$ In addition to 'equality' and the 'right to present one's case', as enunciated in Article 18, other provisions in the Model Law spell out further fair trial rights or guarantees. Determining whether or not proceedings are fair, according to established case law, must be assessed by reference to the proceedings as a whole, ${ }^{10}$ albeit that a substantial departure in one element of the proceedings (eg. the right of the parties to present their case) is sufficient to bring about a breach. For the purposes of arbitration it is noteworthy that the European Court of Human Rights (ECtHR) has developed a line of precedent according to which domestic (long-established) judicial practice may deviate within particular boundaries from Article 6(1) ECHR. ${ }^{11}$ Arbitral proceedings do constitute mutatis mutandis longestablished judicial practice.

\footnotetext{
6 See A Hirsch, 'The Place of Arbitration and the Lex Arbitri' (1979) 34 Arbitration Journal 43; E Gaillard, Legal Theory of International Arbitration (Kluwer 2010) 19-20.

7 Council Directive 86/653/EEC on the coordination of the laws of the member States relating to self-employed commercial agents.

${ }^{8}$ Accentuate Ltd v Asigra Inc [2009] EWHC 2655 (QB).

9 Nideröst-Huber $v$ Switzerland (1998) 25 EHRR 709, para 30.

10 Ankerl v Switzerland (2001) 32 EHRR 1, para 38; Centro Europa 7 S.r.l. and Di Stefano v Italy, (2012) ECHR 974, para 197.

11 Kerojärvi v Finland (2001) 32 EHRR 8, para 42; Gorou v Greece (no. 2) [GC], (2009) ECHR 488, para 32 .
} 
On the basis of the above considerations, although the concept of equality in Article 18 of the Model Law does not have the same underpinnings as its counterpart in general human rights law, it does clearly encompass the notions of non-discrimination and arbitrariness. This is because Article 6 of the European Convention on Human Rights (ECHR) chiefly concerns the right to a fair trial in criminal proceedings - although, as will be seen, it also covers civil and commercial proceedings. ${ }^{12}$ As a result, while the entire range of fair trial guarantees in domestic and international law apply (or should apply) to arbitral proceedings, the permissive nature of arbitration allows for some degree of exceptionalism.

The reason for allowing some departures from established fair trial guarantees is that arbitral proceedings are predicated on contract, whereas judicial proceedings are not. The law not only facilitates, but clearly promotes arbitration on the ground that the parties (other than in consumer arbitration) understand the advantages and disadvantages of arbitration as against litigation. Even so, the law addresses possible fair trial deficiencies when promoting arbitration by limiting the range of disputes that are susceptible to arbitration (so-called arbitrability). Within this framework the law accepts the need for speedier commercial justice at the expense of certain fair trial guarantees which, given that one is dealing with mature commercial actors, do not disproportionately favour one against the other, or which are not arbitrary in their application.

In addition, the law recognises that the type of commercial justice served by arbitration contains inbuilt guarantees that are peculiar and exclusive to arbitration. By way of illustration, appeals are unavailable in arbitral proceedings, not only because the parties desire a speedy resolution of their dispute but also because the 'harm' suffered by the absence of a right to appeal is more than sufficiently remedied by the ability to choose one's arbitrators, as well as the applicable law and procedure. This is not the case in litigation. Similarly, the right to present one's case is not disproportionately prejudiced where a tribunal orders that proceedings are only paper-based in situations where the parties require speedy resolution and the tribunal deems that the proposed witnesses have no probative value.

The limits of exceptionality of arbitral proceedings are where a party is disproportionately and arbitrarily disadvantaged, whether by the actions of a tribunal, or by the application of procedural rules to that effect. Views

\footnotetext{
12 As a result, the ECtHR has held 'that contracting States have greater latitude when dealing with civil cases concerning civil rights and obligations than they have when dealing with criminal cases' Dombo Beheer B.V. v the Netherlands, (1994) 18 EHRR 213, para 32; Levages Prestations Services $v$ France (1996) ECHR 1530, para 46; see also C Ambrose, 'Arbitration and the Human Rights Act' [2000] Lloyd's Maritime and Commercial Law Quarterly 468; C Jarrosson, 'L'Arbitrage et la Convention Européene des Droits de l'Homme' (1989) 4 Revue de l'Arbitrage 573; A Samuel, 'Arbitration, Alternative Dispute Resolution Generally and the European Convention on Human Rights' (2004) 21 JOIA 413. See also MS Kurkela and S Turunen, Due Process in International Commercial Arbitration (2nd edn, Oxford University Press 2010).
} 
expressed in the past by some national courts that Article 6(1) ECHR is inapplicable to consensual arbitral proceedings are no longer sustainable. ${ }^{13}$ The consensual and exceptional nature of commercial arbitration does not result in the fragmentation of the lex arbitri, which, as already explained, encompasses the seat's human rights treaty obligations.

It should be noted that this article does not consider party equality in private international law, whether general or specific, since this rarely comes into play in the process of international arbitral proceedings. ${ }^{14}$ The same is true in respect of consumer arbitration, as many of the applicable rules are either lex specialis or regionally derived, as is the case with EU consumer directives. In such cases, the wide-ranging party autonomy typically associated with international commercial arbitration is severely restricted in favour of the weaker party. Finally, this article does not take into account equal treatment developments in the context of investment arbitration, although the principles applied there are quintessentially the same as those considered in this article.

\section{THE SOURCES OF EQUAL TREATMENT IN ARBITRAL PROCEEDINGS}

From a methodological point of view this article distinguishes between equality and the right to an opportunity to present one's case. Functionally, however, these are not distinct rights. Both are part of the right to a fair trial and to the equality of arms. This suggests that the parties to civil/arbitral proceedings must be afforded equal opportunities, including the right to present their case to the best of their abilities. ${ }^{15}$ What is the exact source of this right in the context of arbitral proceedings? While one could point to arbitration-specific instruments, such as Article 18 of the Model Law and similar provisions in domestic arbitral statutes (both Model Law-adherent and others), the fair trial guarantees set out in such instruments find their origins in general human rights treaties and civil procedure laws and statutes. ${ }^{16}$ It is beyond the scope of this short article to provide an exhaustive account of civil procedure statutes, but it is undoubtedly the case that their fair trial provisions have been shaped by general international human rights law, as well as by the case law of international human rights tribunals. As a result, this article places significant reliance on the case law of the ECtHR. This is justified for a

13 See eg Ferrara v AG 1824, judgment by the Brussels Court of Appeals in 2002, which, however, stressed that arbitrators have a duty to ensure that fair trial guarantees are met.

${ }^{14}$ On this see generally JJ Fawcett, MN Shúilleabháin and S Shah, Human Rights and Private International Law (Oxford University Press 2016).

15 Dombo Beheer B.V. $v$ the Netherlands (n 12) para 33

16 See the discussion above on art 2A of the Model Law, which fully justifies an interpretation of art 18 in accordance with international fair trial standards emanating from human rights treaties and case law. The legal nature of the Model Law entails that in construing questions arising from its application recourse may be had to sources and principles that are external to it, such as treaties, general principles, lex mercatoria and domestic law. See M Gebauer, 'Uniform Law, General Principles and Autonomous Interpretation' (2005) UnifLRev 683. 
variety of reasons. Firstly, the Court's jurisprudence concerning the right to a fair trial is the most extensive among its international counterparts. Secondly, to a large extent it reflects customary international law and general principles of law. ${ }^{17}$ Thirdly, it is part of the lex arbitri of the 47 member States of the Council of Europe, which constitute the bulk of the globe's arbitration fora, not to mention that it may also be an integral part of the governing law of the parties' agreement (for Council of Europe member States). Fourthly, the ECtHR has expressly factored arbitral proceedings into its fair trial guarantees. ${ }^{18}$ Finally, the ECtHR has a well-established doctrine concerning the margin of appreciation, which member States are permitted to exercise when fulfilling their convention obligations. ${ }^{19}$

While general human rights law and domestic civil procedure statutes provide the general framework for fair trial guarantees in arbitral proceedings by setting out general principles, it is their specific application to arbitral proceedings that clearly helps delineate their precise scope and exceptional deviations. Therefore, arbitration-specific instruments (formal, informal or contract-based), as well as judgments by domestic courts, provide greater insights concerning the range of accepted deviations, chiefly because complaints concerning equal treatment will result in set aside proceedings in the seat of arbitration. Article 34(1) and (2) of the Model Law sets out what is beyond doubt a general principle of civil procedure, that:

1. Recourse to a court against an arbitral award may be made only by an application for setting aside ...

2. An arbitral award may be set aside ... only if:

(a) the party making the application furnishes proof that:

(ii) the party making the application was not given proper notice of the appointment of an arbitrator or of the arbitral proceedings or was otherwise unable to present his case.

Although the Model Law identifies other fair trial guarantees, Articles 34(2)(ii) and 22 permit injured parties to seek annulment (set aside) of awards that offend party equality. Given the unique nature of arbitral proceedings, it is important that the right to equality, as developed in the jurisprudence of the ECtHR, be read against seminal commercial arbitration instruments, and in particular the Model Law, in a manner that renders them consistent and complementary, in accordance with Article 2A of the Model Law.

\footnotetext{
17 The literature on the application of equality and fair trials to civil proceedings is sparse. However, available works stipulate that procedural equality is a general principle of law. See OJ Settem, Applications of the Fair Hearing Norm in ECHR Art 6(1) to Civil Proceedings (Springer 2015) 96-121.

18 See eg Klausecker v Germany [2015] EHRR SE8, paras 69-77; Deweer v Belgium (1979-80) 2 EHRR 439, para 49; Tabbane v Switzerland (2016) ECHR 109, para 27; Lithgow and Others $v$ UK, (1986) 8 EHRR 329, para 201,

19 See G Letsas, 'Two Concepts of the Margin of Appreciation' (2006) 26 OJLS 705.
} 
III. FAIR TRIAL AND EQUALITY IN THE TRAVAUX PRÉPARATOIRES OF THE MODEL LAW

Whilst Article 18 of the Model Law expresses a general principle of law, its travaux préparatoires provide little, if any, indication of its linkages with fair trial rights as a principle of international human rights law, as opposed to a fundamental principle of civil procedure. Even so, Article 2A of the Model Law stresses that States must interpret the Model Law in accordance with its international character and with the aim of achieving uniformity on the basis of general principles and good faith. Quite clearly, Article 18 must be construed in a manner that is consistent with the member States' human rights obligations and general principles of law, including fair trial guarantees.

The source of fundamental procedural rights in the original formulations of the 1985 version of the Model Law was not always clear. ${ }^{20}$ The basis in the first rounds of drafts was Article 15(1) of the UNCITRAL Arbitration Rules. ${ }^{21}$ In October 1982 the two elements of procedural fairness were placed in Article 19(1)(9b). ${ }^{22}$ This remained the case at the fourth session, although it was observed that the right to present one's case should not apply 'at any stage' of the proceedings, as then provided for in draft Article 19(1)(b), since this would allow parties to prolong proceedings or make unnecessary submissions. ${ }^{23}$ It was also suggested that the obligation to communicate all information supplied to the tribunal to the other party in draft Article 20(2) should perhaps also be placed in the equality provision of Article 19(1)(b). ${ }^{24}$ At its fifth session, the Working Group set out a draft Article 19 consisting of two paragraphs. The second paragraph limited a tribunal's authority to devise procedural rules unless authorised to do so by the parties, noting that such authority was subject to the parties' right of equal treatment and their right to present their case. ${ }^{25}$ This formulation was accepted verbatim in subsequent sessions. ${ }^{26}$

During the ninth session very few comments were made concerning procedural fairness in comparison to other provisions. Norway suggested that violations of the right to present one's case should give rise to set aside proceedings against the award. Both Norway and the International Bar Association further suggested that rather than referring to the opportunity of

20 See, for example, Report of the Working Group on International Contract Practices on the Work of its Sixth Session, UN Doc A/CN.9/245 (22 September 1983), where no reference is made.

21 Note by the Secretariat: Model Law on International Commercial Arbitration: Draft Articles 124, UN Doc A/CN.9/WG.II/WP.37 (1982) 54, fn 34. It should be noted that the UNCITRAL Arbitration Rules, originally adopted in 1976, were meant to serve as a detailed set of procedural rules for arbitral tribunals that were not operating under institutional rules.

23 Report of Working Group II, UN Doc A/CN.9/232 (1982), para 104.

24 ibid, para 110.

25 Note by the Secretariat: Model Law on International Commercial Arbitration: Revised Draft Articles I to XXII, UN Doc A/CN.9/WG.II/WP.40 (14 December 1982), Draft art XV.

26 Working Papers submitted to the Working Group at its Seventh Session, Composite Draft Text of a Model Law on International Commercial Arbitration: Note by the Secretariat, UN Doc A/CN.9/ WG.II/WP.48, reprinted in XV (1984) YB UNCITRAL 218, at 223. 
presenting its case in 'full', the reference should be to having an 'adequate' opportunity to do so, or the words 'and proper' should be added after 'full' ${ }^{27}$ The absence of comments certainly indicates that procedural fairness was not high on the agenda and that neither UNCITRAL nor participating States properly understood the interaction between the right to a fair trial and its application to arbitral proceedings. The final version of the 1985 Model Law ultimately preserved a distinct provision on procedural fairness, thus distinguishing this foundational issue from the remainder of Article 19.

When the current version of Article 18 was still draft Article 19(3), party equality was only one dimension of three distinct, yet interrelated, issues, namely: a) the parties' freedom to set out arbitral procedure; b) the tribunal's authority to determine such procedure where the parties had not done so; c) as well as to further determine the admissibility, relevance and materiality of evidence. The official UNCITRAL Commentary emphasises the importance of draft Article 19 by calling it the 'Magna Carta of Arbitral Procedure'. It clearly states that it is not subject to derogation, even by the parties themselves. ${ }^{28}$ Moreover, it reiterates the fundamental nature of 'fairness' as set out in draft Article 19(3) and makes it clear that it applies to other pertinent provisions in the Model Law requiring procedural fairness. Although the official commentary does not offer an exhaustive analysis, it does make an important point, namely that the right to present one's case 'does not entitle a party to obstruct the proceedings by dilatory tactics and, for example, present any objections, amendments, or evidence only on the eve of the award'.29

Ultimately, paragraph 3 was removed and placed separately in Article 18. The first two paragraphs of draft Article 19 remained as they were. This was meant to distinguish between the somewhat different issues of party autonomy to determine rules of procedure and procedural fairness, while at the same time emphasising the importance of procedural fairness by underlining that it is not subordinate to the freedom of the parties to determine procedural rules. In draft Article 19(3), the words 'in either case' were added to the beginning of the sentence. These were removed from the final text of Article 18. Article 18 remained unchanged in the revision of the Model Law in 2006. Whilst UNCITRAL is not averse to human rights influences, it should not be assumed that commercial law experts have a clear understanding or appreciation of the role of human rights. This perhaps helps explain why there was no express reference to fair trial rights in the travaux. Even so, the scope and content of the principles which were set out reflect general principles of fair trial proceedings in civil procedure legislation,

27 Analytical Compilation of Comments by Governments and International Organisations on the Draft of a Model Law on International Commercial Arbitration, Report by the Secretary-General, UN Doc A/CN.9/263 (19 March 1985) 33.

${ }_{28}$ UNCITRAL, Analytical Commentary on the Draft Text of the Model Law, UN Doc A/CN.9/ 264 (25 March 1985) 45. 
which in turn has largely been shaped by regional or universal human rights treaties.

\section{LIMITATIONS TO PARTY AUTONOMY: FAIR TRIAL GUARANTEES}

The parties' control of arbitral proceedings is not unlimited. Arbitral proceedings are legal proceedings, even if arbitral tribunals are not always perceived as having been 'established by law',30 and arbitral proceedings are therefore subject to fair trial guarantees in the manner explained above. As already emphasised, the human rights obligations of the seat (and perhaps those of the country of enforcement) must be taken into account in the conduct of the proceedings. ${ }^{31}$ The seat's human rights obligations are part of its lex arbitri and the tribunal would fail in its duty to produce an enforceable award were it to ignore the human rights obligations of the seat and of the intended country of enforcement. Although one cannot require arbitrators to be appraised of the expanding jurisprudence of the ECtHR and that of other human rights courts and tribunals, arbitral institutions and counsel must ensure, and typically do, that the parties' procedures are compliant with fundamental fair trial guarantees. ${ }^{32}$

In practice, courts interpret the right to fair and equal treatment in arbitral proceedings restrictively. The South African Constitutional Court in Lufuno Mphaphuli \& Associates (PTY) Ltd. $v$ Nigel Athol Andrews Bopanang Construction $C C$ was asked to set aside an award because of three 'secret' meetings between the arbitrator and the respondent during the course of the arbitration and also because not all correspondence between the respondent and the arbitrator was furnished to the appellant. The appellant relied on Article 34 of the RSA Constitution, which provides for a right of a public

30 See Case 102/81 Nordsee Deutsche Hochseefischerei GmbH v Reederei Mond Hochseefischerei Nordstern AG and others [1982] ECR 1095; Case C-394/11 Belov v CHEZ Elektro Balgaria and Others, CJEU judgment (31 January 2013), para 38; Case C-125/04 Denuit and Cordenier v Transorient - Mosä̈que Voyages et Culture SA [2005] ECR I-00923, para 13; C-555/13 Merck Canada v Accord Healthcare Ltd and Others, CJEU judgment (13 February 2014), para 17, whereby the CJEU does not generally view arbitral tribunals as established by law, but this largely concerns the capacity of arbitral tribunals to request preliminary rulings.

31 Transado - Transportes Fluviais do Sado v Portugal, App No 35943/02, Eur Ct HR judgment (16 December 2003); see equally Nordsee Deutsche Hochseefischerei GmbH v Reederei Mond Hochseefischerei Nordstern AG and others, Case 102/81 [1982] ECR 1095, where the CJEU held that the application of EU law cannot be limited by contractual exceptions or carve outs; equally, Société Licensing Projets and others v Société Pirelli \& C SpA and others, Paris Appeals Court judgment (17 November 2011). See also art 396(2) of the Swiss CCP, which allows a limited review of domestic arbitral awards where the claimant alleges a violation of the ECHR.

32 See art 22(1) ICC Rules, which provides that both the parties and the tribunal must ensure that the proceedings are conducted in a cost-effective and expeditious manner. If an award is not compliant with the right to fair trial it will be set aside. See G Petrochilos, Procedural Law in International Arbitration (Oxford University Press 2004) 112-13. 
hearing in respect of disputes. The Court held that arbitral tribunals are not directly covered because hearings are not public and arbitrators are not necessarily independent, at least in the sense of court judges. The Court further relied on Article 18 of the Model Law and section 33 of the English Arbitration Act, which it found to enshrine a constitutional principle, albeit that it held fairness to be a creature of context.

In the particular context of the case, it pointed out that the arbitrator was a quantity surveyor and the parties' agreement adopted an informal methodology for the proceedings. The Court further argued that the 'secret' meetings did not prevent the parties from presenting their case fairly and rejected the contention that the correspondence not being furnished to the appellant constituted a gross irregularity because each party had had an opportunity to persuade the arbitrator that his preliminary conclusions were wrong. ${ }^{33}$ Although other national courts might reach different conclusions regarding the appellant's irregularity claims, the judgment is at pains to emphasise the sui generis nature of procedural equality in arbitration, which may well be dispensed by informal means. This line of reasoning was taken even further by the Court of Appeal of Katowice, which held that an arbitrator's lack of impartiality only violates Article 18 of the Model Law if it results in inequality between the parties. ${ }^{34}$

Two principles are universally accepted as being applicable in arbitral proceedings, namely: due process and fair hearing, and the independence and impartiality of the tribunal. ${ }^{35}$ Due process is a broad principle encompassing many different aspects of the proceedings. Its most salient manifestation is party equality, guaranteed by Article 6 ECHR, according to which even if the agreement between the parties indicates otherwise, the tribunal must treat all litigants in the same manner without any distinction or discrimination. ${ }^{36}$ Essentially, what is allowed for one party should equally be allowed to the other. Because of their foundational (and binding) nature, the rights enshrined in Article 18 cannot be waived by the parties. This is true both as regards the mandate of the tribunal (concerning its treatment of the parties), as well as the right of the parties to contest the propriety of arbitral proceedings on the ground of unfair treatment. ${ }^{37}$

Although a handful of national courts have erroneously assumed that the latter right can be waived ${ }^{38}$ it should be remembered that: a) fundamental

\footnotetext{
33 Lufuno Mphaphuli \& Associates (PTY) Ltd. v Nigel Athol Andrews Bopanang Construction $C C$, [2009] ZACC 6, CLOUT Case 1691.

34 A. L. v. (...) Spótka Akcyjna v P, CLOUT Case 1465.

35 See I Bantekas, Introduction to International Arbitration (Cambridge University Press 2015) $123-6$.

36 This is clearly a foundational principle from which no derogation, even by the parties' consent, is permitted. See Soh Beng Tee \& Co. Pte. Ltd. v Fairmount Development Pte. Ltd. [2007] 3 SLR (4) 86, CLOUT Case 743; Noble China Inc. v Lei Kat Cheong [1998] CanLII 14708 (ON SC).

37 See Noble China Inc. v Lei Kat Cheong, ibid.

38 Methanex Motunui Ltd. v Spellman [2004] 3 NZLR 454.
} 
human rights rules can never be the subject of derogation; b) Article 4 of the Model Law expressly states that parties may only waive non-mandatory requirements, and c) there is always a risk that such purported waiver could be due to coercion, fear or intimidation, which is why such rights are not and should not be amenable to waiver. However, the foundational rules enshrined in Article 18 are not meant to retrospectively shield the parties from poor and deliberate choices during the arbitral process. ${ }^{39}$

Fair trial guarantees not only apply to the proceedings as such, but should also extend to the preliminary assessment of the validity of the submission agreement since if such an agreement is unfair, this might prejudice the equal treatment of the parties. Hence, if the arbitration agreement gives rise to some form of inequality that unfairly prejudices one party, the court or tribunal is obliged to declare that part of the agreement null and void. Some courts have shown willingness to unreasonably stretch the principle of equal treatment by applying quantitative standards to measure equality. For example, in a Polish case, Iwona G. v A. Starosta $i$ Wspólnicy spótka jawna w B, the arbitration agreement provided that the tribunal be constituted by a super-arbitrator who was to be appointed by arbitrators nominated by each shareholder in the company. The claimant argued that since he was only able to appoint one of the seven arbitrators his interests were not equally represented. The Court of Appeals of Bialystok considered this to violate the principle of party equality. ${ }^{40}$

\section{A. Non-Applicability of Fair Trial Guarantees}

Fair trial guarantees may not apply in arbitral proceedings if this does not run counter to mandatory (ie non-permissive) rules or sub-rules related to equal treatment. Some examples have already been mentioned in previous sections. The general rule clearly seems to be that any action that does not prejudice equality or procedural fairness between two knowledgeable and mature commercial parties may be permissible. The law assumes a priori that those permitted to enter into an arbitration agreement possess sufficient business acumen and understand both the advantages and disadvantages of doing so as compared with litigation. As a result, minor imbalances that are not arbitrary, which do not create inequality and which, moreover, serve the purposes of commercial justice will be sustained.

An obvious example concerns power disparities between the parties. Although it is sensible to bridge power gaps between parties in court proceedings, it is, for example, inconceivable that the stronger party (other than in consumer arbitration, which is beyond the scope of this article) should bear the legal or other expenses of the weaker (ie the party with less resources) party solely on

39 Re Corporación Transnacional de Inversiones, S.A. de C.V. et al. v STET International, S.p.A. et al., [1999] CanLII 14819 (ONSC), CLOUT Case No. 391.

${ }^{40}$ Iwona G. v A. Starosta $i$ Wspólnicy spótka jawna w B, CLOUT Case 1467. 
the ground of financial disparity between them. ${ }^{41}$ The German Federal Supreme Court has approached this issue from a contractual perspective, holding that where a party to an agreement containing an arbitration clause is genuinely unable to finance the costs associated with arbitration, then the arbitration agreement is incapable of performance and the indigent party may seek to resolve the dispute through the courts and receive legal aid. ${ }^{42}$ Clearly, this contractual line of reasoning is only indirectly concerned with procedural guarantees and should not be relied as a general rule to confer such guarantees.

Another example concerns exclusion clauses in commercial contracts that seek to waive the rights of the parties to litigate before ordinary courts. It is now well established that such exclusion clauses do not prejudice fair trial guarantees in and by themselves. ${ }^{43}$ Free and open consent is paramount because agreements providing for mandatory arbitration have not always been considered compliant with the right to a fair trial. ${ }^{44}$ Other examples are given in the sections that follow.

\section{EQUALITY OF ARMS}

The fundamental starting point for assessing 'equality' outside the context of Article 18 of the Model Law is Article 6(1) ECHR, ${ }^{45}$ which stipulates that 'in

41 Exceptionally, the Portuguese Supreme Court in Wall Street Institute de Portugal - Centro des Ingles SA WSI-Consultadoria e Marketing and others $v$ Centro des Ingles Santa Barbara LDA, judgment no 311/2008 (30 May 2008), held that where a party to arbitral proceedings had become indigent it was entitled to legal aid and so could have recourse to litigation instead of arbitration. The Court's rationale was that the interest sacrificed by the rejection of the arbitration clause was purely procedural and doing so protected the substantive interest of the right to a fair trial. This approach is very unusual and is generally rejected. See art 380 of the Swiss CCP, which excludes the possibility of legal aid from domestic arbitral proceedings. The Swiss Federal Supreme Court in case no 4A_178/2014, judgment (29 July 2014) confirmed that the same exclusion applies also to international arbitrations; equally D.L.T. Holdings Inc. v Grow Biz International, decided by Canada's Prince Edward Island's Supreme Court, [2001] 199 Nfld. \& Prince-Edward-Island Reports 135, CLOUT Case 501. The Court held that disparities between the parties in financial bargaining power did not offend public policy.

${ }^{42}$ CLOUT Case 404, III ZR 33/00 1(4 September 2000).

43 In Sumukan Limited v Commonwealth Secretariat [2007] EWCA Civ 243, the English Court of Appeal held that an agreement in an arbitration clause to exclude appeal to a court on a point of law under section 69 of the Arbitration Act 1996 (the exclusion agreement) did not breach the right to a fair trial as guaranteed under art 6 of the ECHR. Equally, as far back as the early $1960 \mathrm{~s}$, in Osmo Suovaniemi and Others $v$ Finland, App No 31737/1996, Decision (23 February 1999) and $X v$ Germany, App No 1197/1961, Decision (5 March 1962), the EurCtHR and the Commission stressed that waivers in favour of exclusive arbitration are consistent with the right to a fair trial.

44 Bramelid and Malstrom $v$ Sweden (1983) 5 EHRR 249. Conversely, the Maltese Constitutional Court has held that mandatory arbitration proceedings under Maltese law (including the appointment of arbitrators by the chairman of the Malta Arbitration Centre) did not breach either the Constitution of Malta (art 39(2)) or the right to fair trial under art 6(1) of the ECHR. Untours Insurance Agency Ltd and Emanuel Gauci v Victor Micallef and Others, App No 81/2011/1, Maltese Constitutional Court judgment (25 January 2013).

45 The same principle is found also in other international instruments, such as arts 14 and 16 ICCPR; art 10 UDHR; arts 3, 7 and 26 of the African Charter on Human and Peoples' Rights (ACHPR); arts 3, 8-10 American Convention of Human Rights (ACHR). 
the determination of his civil rights and obligations ... everyone is entitled to a fair ... hearing by [a] tribunal ...'. Fairness applies to the entirety of proceedings and not simply oral hearings or proceedings on the merits. ${ }^{46}$ Courts and arbitral tribunals must provide all parties with a fair opportunity to effectively argue their case and make their claims. Moreover, it also imposes an obligation on courts and tribunals to treat the parties fairly, that is, without bias or arbitrariness, when reaching their decision.

In the course of a sports-related arbitration, for example, the tribunal relied on an unlawfully obtained video recording that ultimately proved to be decisive. The Swiss Federal Supreme Court held that the admission of otherwise unlawful evidence did not breach a fundamental principle of Swiss procedural law. It went on to note that tribunals, just like courts, possess the authority to undertake a case-specific assessment of whether illegally obtained evidence should be admitted or not. ${ }^{47}$

In this author's view, the principle of equality of arms best expresses the particular concept of 'equality' in Article 18 as it applies to adversarial arbitral proceedings. This principle requires that the opportunities afforded to both (all) parties in adversarial proceedings are fairly balanced. The 'fairness' required by Article 6(1) ECHR is concerned with 'procedural' fairness, as opposed to substantive fairness (which relates to inherent powers of courts and tribunals). The procedural fairness guaranteed by the right to a fair trial in civil and arbitral proceedings necessitates that in adversarial proceedings the parties and their submissions are treated equally, even if one ultimately prevails over another. The ECtHR sensibly does not regard an isolated procedural unfairness as tainting the entire process, ${ }^{48}$ though this rule should be applied with caution in arbitration.

Equality of arms further necessitates that the parties have access to all admissible evidence and a fair opportunity to comment on, and examine, such evidence, even with respect to its authenticity. ${ }^{49}$ Article 24(3) of the Model Law provides that all statements, documents and other information supplied to the arbitral tribunal by one party shall be communicated to the other party, and that any expert report or evidentiary document on which the arbitral tribunal may rely in making its decision shall be communicated to the parties. ${ }^{50}$ This places even greater emphasis on the requirement of wellreasoned awards because it allows the courts to assess if, and to what degree,

\footnotetext{
46 Stran Greek Refineries and Stratis Andreadakis v Greece (1994) 19 EHRR 293, para 49.

47 Joined cases 4A_362/2013 and 4A_448/2013 judgment (28 May 2014).

48 Mirolubovs and Others $v$ Latvia, App No 798/05 ECtHR judgment (15 September 2009) para 103

49 Krčmár and Others v the Czech Republic, App No 35376/97, ECtHR judgment (2 May 2000) para 42; Immeubles Groupe Kosser v France, App No 38748/97, ECtHR judgment (9 March 1999) para 26.

50 See Attorney-General v Tozer (No 3), High Court, Auckland, New Zealand, (2 September 2003), whereby an award was set aside because a document submitted to the tribunal by one party was excluded from its file to the other party.
} 
a tribunal was partial in its treatment of the evidence and the parties' ability to produce such evidence.

Although the tribunal need not necessarily attach probative value to all evidence brought forth by the parties, it must allow them to at least submit it if a party deems it to be relevant to proving its case. ${ }^{51}$ The equality of arms principle mandates that the parties must be granted a fair opportunity to express their views on all admissible documents, even those introduced by the tribunal on its own motion. ${ }^{52}$ However, there exists no obligation to transmit to the other party documents that are either inadmissible or those that have not been presented to the tribunal. ${ }^{53}$ Withholding of evidence from one party is only permissible under reasons of strict confidentiality or for reasons relating to public safety or witness protection. ${ }^{54}$

The ECtHR has emphatically stressed that courts and tribunals are at liberty, whether their authority is derived by contract or statute, to lay down their own rules of evidence ${ }^{55}$ and decide on matters of admissibility of evidence. ${ }^{56}$ Courts and tribunals have the power to determine the probative value of evidence and administer the burden of proof, provided, of course, that the pertinent rules are known to the parties in advance. ${ }^{57}$ This is consistent with arbitral practice, whereby rules of procedure and evidence are predicated on the parties' agreement. In a case decided by the Singapore Court of Appeals it was held that an interim award relying on facts not included in the parties' pleadings did not violate the right to equal treatment because the applicant had ample notice of the claim in question and ample opportunity to address it. Hence, it did not suffer any prejudice as a result of the issue not being contained in the pleadings. 58

Other than in respect of evidence-related issues, the ECtHR has found a breach of the equality of arms principle, where: a) an action was brought by one party, without this being communicated to the other; ${ }^{59}$ b) of several key witnesses put forward by the parties only one was heard;60 c) one party

51 Clinique des Acacias and Others v France, App No 65399/01, ECtHR judgment (13 October 2005) para 37.

52 Pellegrini v Italy, (2002) 35 EHRR 2, para 45); K.S. v Finland, App No 29346/95, ECtHR judgment (31 May 2001) para 22; Nideröst-Huber v Switzerland (n 9) para 29.

${ }_{53}$ Yvon v France (2005) 40 EHRR 4, para 38.

54 Užukauskas v Lithuania, App No 16965/04, ECtHR judgment (6 July 2010) para 51; Pocius v Lithuania, App No 35601/04, ECtHR judgment (6 July 2010) paras 52-53.

55 Mantovanelli v France, (1997) 24 EHRR 370, para 34.

56 Moreira de Azevedo v Portugal (1991) 13 EHRR 721, paras 83-84; García Ruiz v Spain [GC], (1999) 31 EHRR 589, para 28.

57 Centro Europa 7 S.r.l. and Di Stefano v Italy (n 10) para 19.

58 PT Prima International Development v Kempinski Hotels SA [2012] SGCA 35, CLOUT Case 1663. $\quad{ }^{59}$ Beer v Austria, App No 30429/96, ECtHR judgment (6 February 2001) para 19.

${ }^{60}$ Dombo Beheer B.V. v the Netherlands (n 12) paras 34-35. This may be remedied by providing a reasoned explanation, showing that the refusal was not arbitrary. See Wierzbicki v Poland (2004) 38 EHRR 38, para 45. 
enjoyed significant advantage with regard to particular information, which placed its opponent at an acute disadvantage; ${ }^{61} \mathrm{~d}$ ) the judge/arbitrator refused to adjourn a case even though one of the parties was taken to emergency care and its lawyer was unable to represent him at the hearing, thus causing irreparable harm. ${ }^{62}$ Although the ECtHR has held that the absence of legal aid in cases involving significant financial disparity between the parties may be detrimental to the weaker party in presenting its case, ${ }^{63}$ there is no general right to legal aid in arbitral proceedings.

Although we have already explained that procedural fairness encompassed under the right to fair trial does not have a substantive aspect, the ECtHR has identified some narrow instances where the tribunal's dispositive function may come under scrutiny, particularly where the tribunal's errors are manifest and infringe rights and freedoms protected by the Convention. ${ }^{64}$ Just as in the practice of national courts, where it is exceptionally rare for the courts of the seat to set aside awards because of errors of law or substance, equally the ECtHR has done so sparingly in exceptional cases of manifest error of judgment, which render the judgment arbitrary or manifestly unreasonable. ${ }^{65}$ The ECtHR reached the same conclusion where the judgment constituted a denial of justice ${ }^{66}$ or where the court's reasoning was regarded as being 'grossly arbitrary'. ${ }^{67}$

The ECtHR has emphasised that the courts need not follow precedent, since this hinders the evolutive and dynamic development of the law ${ }^{68}$ and restricts the kompetenz-kompetenz power of courts and tribunals. Exceptionally, divergences in case law (and the litigants' legitimate expectations) may constitute a violation of Article 6(1) ECHR where the divergences are profound and long-standing and the State in question possess sufficient judicial mechanisms to resolve such divergences but these have not been followed to the detriment of the complainant. ${ }^{69}$ Clearly, such an exception cannot find application in the field of international commercial arbitration, given the absence of any sort of precedent, particularly since the parties

61 Yvon v France (n 53) para 37.

62 Vardanyan and Nanushyan v Armenia, App No 8001/07, ECtHR judgment (27 October 2016) paras 88-90.

63 Steel and Morris v the United Kingdom, (2005) 41 EHRR 22, para 72. See also Wall Street Institute de Portugal - Centro des Ingles SA WSI-Consultadoria e Marketing and others $v$ Centro des Ingles Santa Barbara LDA (n 41).

${ }^{64}$ Garcia Ruiz v Spain (n 56) para 28; Perez v France (2005) 40 EHRR 39, para 82.

65 Dulaurans v France (2001) 55 EHRR 45, para 38; Khamidov v Russia [2007] ECHR 928, para

170. $\quad{ }^{66}$ Anđelković v Serbia, App No 1401/08, ECtHR judgment (9 April 2013) para 24.

67 Bochan v. Ukraine (no. 2), App No 22251/08, ECtHR (5 February 2015) paras 63-65; Barać and Others $v$ Montenegro [2011] ECHR 2101, paras 32-34.

68 Sahin and Sahin v Turkey [GC], App No 13279/05, ECtHR judgment (20 October 2011) para 58; Lupeni Greek Catholic Parish and Others v Romania [GC], [2016] ECHR 1061, para 116.

69 Beian v Romania (no. 1), App No 30658/05, ECtHR judgment (6 December 2007), paras 37 and 39; Lupeni Greek Catholic Parish and Others $v$ Romania, ibid, paras 116-135. 
dictate the applicable law. ${ }^{70}$ Even if the tribunal were to disregard established law, hence effectively erring in its application of the law, the award would still be valid, unless, of course, this was the product of bias against one of the parties.

The courts of the seat have approached Article 18 violations through several lenses. While the rights enshrined in Article 18 of the Model Law are articulated as human rights in human rights treaties, they are equally prescribed as 'freedoms', 'civil liberties', 'natural justice guarantees' or 'due process guarantees' in constitutional or other domestic law. Other designations may well apply, but they all refer to an individual right in judicial or arbitral proceedings.

In $A M Z v A X X,{ }^{71}$ the Singapore High Court was seised of a set aside request that concerned, among others, a violation of Article 18 of the Model Law. The plaintiff had argued during the arbitral proceedings the existence of three serious breaches of contract, but the tribunal only found one, and rejected the existence of a fundamental breach. The plaintiff applied to set aside the award, inter alia, because the tribunal had breached rules of natural justice under Articles 34(2)(a) (ii) and 18 of the Model Law because he was unable to present his case and/or the arbitrator was biased against the plaintiff, and argued that this breach caused actual prejudice.

The Court held that there are two rules of natural justice. The first requires that the tribunal be impartial in appearance and in reality. The second rule of natural justice is audi alteram partem, and the Court outlined several aspects of this rule. ${ }^{72}$ First, tribunals must give parties a chance to be heard on all issues. ${ }^{73}$ Second, tribunals cannot disregard a submission without directing their judicial mind to it. Third, tribunals do not need to refer every issue that falls for decision to the parties for submissions. ${ }^{74}$ Fourth, a tribunal's decision will only be unfair when a reasonable litigant in the position of the party challenging the award could not have foreseen the possibility of the tribunal's actual reasoning in the award. Finally, tribunals can legitimately arrive at a decision that is not covered by the parties' submissions provided its finding is supported by evidence and is not a dramatic departure from the parties' positions.

Applying these principles, the Court held that there had not been a breach of the audi alteram partem rule as the tribunal had applied its mind to the plaintiff's arguments. It found that the tribunal had actually considered some of the plaintiff's arguments when it was not necessary for it to do so to come to its decision. The Court also pointed out that it was not the tribunal's duty to advise plaintiffs on how to best frame their own arguments. Therefore, the Court rejected the plaintiff's first submission in its entirety. ${ }^{75}$

\footnotetext{
${ }^{70}$ But see exceptionally, section 69 of the English Arbitration Act, which allows appeals on points of law.

72 ibid, paras 91-94.

${ }^{71} A M Z v A X X[2015]$ SGHC 283, CLOUT Case 1660.

73 ibid, para $95 . \quad 74$ ibid, para $97 . \quad 75$ ibid, paras $106 \mathrm{ff}$.
} 
VI. FULL OPPORTUNITY TO PRESENT ONE'S CASE

\section{A. The General Rule}

The general rule in arbitral proceedings is that parties must be able to present their case effectively. ${ }^{76}$ Fair trial case law clearly suggests that the parties to civil proceedings have the right to present the observations they regard as relevant to their case. Although, there is some latitude in arbitral proceedings as to the inherent power of the tribunal to ignore what it considers irrelevant or frivolous, this authority can only be seen to be effective if the observations of the parties are actually 'heard'. ${ }^{77}$ The ECtHR has construed the right to effectively be heard as encompassing a duty on the tribunal to conduct the proceedings by means of a proper examination of the parties' submissions, including arguments, claims and counter-claims. ${ }^{78}$

In most cases where a violation of the right to present one's case is alleged, claimants generally argue that insufficient weight has been given to their evidence or that the tribunal has prevented them from making lengthier submissions on a point they perceived as central to their case. In a New Zealand case concerning an award for the value of land, the plaintiff sought to set aside the award for breach of natural justice, alleging a lack of opportunity to be heard as to the approach used by the arbitrators to assess the value of the land. The New Zealand High Court relied on Article 18 of the Model Law and Article 18 of the country's Arbitration Act.

In order to substantiate 'surprise' as a procedural irregularity giving rise to a breach of natural justice, the plaintiff was required to show: (a) that a reasonable litigant in the plaintiff's position would not have foreseen the reasoning on the part of the arbitral tribunal of the type laid down in the award; and (b) that with adequate notice it might have been possible to convince the arbitral tribunal to reach a different result. The Court observed that, once a party could show 'significant surprise', it is reasonable to assume that, lacking any evidence to the contrary, some procedural prejudice had actually occurred. ${ }^{79}$

In a similar case where the tribunal unilaterally fixed a hearing date and refused requests for adjournment of the hearing, it was found not to have afforded the party a reasonable opportunity to present its case. ${ }^{80}$ The same was true in a Swiss case where the tribunal based its award on a legislative provision that was 'manifestly non-applicable' to the circumstances of the arbitration and could not therefore have been anticipated by the parties. ${ }^{81}$

76 H v Belgium, (1987) 10 EHRR 339, para 53.

77 Donadze v Georgia, App No 74644/01, ECtHR judgment (7 March 2006) para 35.

78 Kraska v Switzerland, App No 13942/88, ECtHR judgment (19 April 1993) para 30; Van de Hurk $v$ the Netherlands, (1994) 18 EHRR 481, para 59; Perez v France [GC] (n 64) para 80.

79 Auckland Trustees of Rotoaria Forest Trust v Attorney-General [1999] 2 NZLR 452, CLOUT Case 658.

${ }^{80}$ Coromandel Land Trust Ltd. v Milkt Investment Ltd, High Court, Hamilton, NZ (28 May 2009).

81 Case 4A_400/2008, (ASA (2009) 3 ASA Bull 495, judgment of the Federal Supreme Court, Switzerland. 


\section{B. Oral Hearings}

Just as in the case of written pleadings, institutional rules of arbitral institutions do not contain detailed regulation of oral hearings. In fact, the parties are perfectly free to dispense with oral hearings if they are content that a documents-only process suffices to present their evidence. This possibility is also contained in Article 24(1) of the Model Law which provides that, unless the parties have agreed that no oral hearings be held for the presentation of evidence or for oral argument, the arbitral tribunal shall hold such hearings at an appropriate stage of the proceedings, if so requested by a party.

The Swiss Federal Supreme Court in re TA G v H Company held that the right of the parties to be heard does not include a right to be heard orally, so long as this rule is consistently applied and is not fundamentally opposed to the wishes of the parties. ${ }^{82}$ The same Court has held, however, that the right to be heard includes a minimum duty to examine all issues material to the outcome of the case, as counterbalanced with the freedom of the tribunal to afford the weight it chooses to the available evidence. ${ }^{83}$

The parties' demand for flexibility, cost-efficiency and speed entails that the hearing process should not conform to the hearing rules of either civil law or common law jurisdictions. In practice, the duration of oral proceedings is short and arbitrators have a duty to ensure that the parties' counsel do not unnecessarily prolong the process, whether by examining immaterial or already discussed evidence, or simply by taking their time with witnesses. ${ }^{84}$ Irrespective of the manner in which the tribunal chooses to implement this duty it must not discriminate between the parties. If the tribunal is able to allocate only a limited number of days to the oral proceedings it should devise a case management strategy to ensure effective and timely completion. It will, in all likelihood, convene a pre-hearing conference with the parties for this purpose where, after hearing their views, it will make an order as to the sequence of actions and the procedures to be followed. ${ }^{85}$

Some of the issues will have already been submitted to the tribunal through the parties' memorials. This may be true of witness and expert statements, in which case the tribunal may decide that there is no compelling reason why

82 Re TA G v H Company, (1997) ASA Bull 316; equally, in CLOUT Case 659, the Oberlandesgericht Naumburg held that the refusal of a tribunal to hold an oral hearing does not violate the right to be heard. It further held that the principle of oral hearing contained in art 128 ZPO did not apply in arbitral proceedings to the same extent as in court proceedings. Thus, in arbitral proceedings the right of the parties to be heard is respected if the parties have at least the possibility to file a statement of defence. In the case at hand the tribunal's determination to conduct a documents-only process was known to the claimant, who failed to object.

${ }^{83}$ Case 4A_669/2012 Swiss Federal Supreme Court judgment (17 April 2012).

84 Art 8(2) IBA Rules.

85 For an excellent guide, see New York State Bar Association, 'Guidelines for the Arbitrator's Conduct of the Pre-Hearing Phase of International Arbitrations' available at: <https://www.adr.org/ sites/default/files/document_repository/NYSBA\%20Guidelines\%20for\%20the \%20Arbitrator's\% 20Conduct.pdf $>$. 
they should be presented again. Exceptionally, where the parties question the truth or integrity of these statements, or the people who made them, the tribunal shall permit a degree of cross-examination, but will set the boundaries concerning the conduct of counsel in this respect. Equally, in its case management function, the tribunal will probably also demand prehearing briefs by the parties with a view to summarising and exposing the oral evidence which the parties seek to rely upon. ${ }^{86}$

The sequence of presentations and the responses or objections by one party against the claims of the other usually follow the procedures adopted in adversarial civil litigation proceedings. Article 8(3) of the International Bar Association (IBA) Rules on the Taking of Evidence, which follows established practice, provides that the sequence may be as follows:

(a) the claimant shall ordinarily first present the testimony of its witnesses, followed by the respondent presenting the testimony of its witnesses;

(b) following direct testimony, any other party may question such witness, in an order to be determined by the arbitral tribunal. The party who initially presented the witness shall subsequently have the opportunity to ask additional questions on the matters raised in the other parties' questioning;

(c) thereafter, the claimant shall ordinarily first present the testimony of its partyappointed experts, followed by the respondent presenting the testimony of its party-appointed experts. The party who initially presented the partyappointed expert shall subsequently have the opportunity to ask additional questions on the matters raised in the other parties' questioning;

(e) if the arbitration is organised into separate issues or phases (such as jurisdiction, preliminary determinations, liability and damages), the parties may agree or the arbitral tribunal may order the scheduling of testimony separately for each issue or phase;

(f) the arbitral tribunal, upon request of a party or on its own motion, may vary this order of proceeding, including the arrangement of testimony by particular issues or in such a manner that witnesses be questioned at the same time and in confrontation with each other (witness conferencing);

(g) the arbitral tribunal may ask questions to a witness at any time. ${ }^{87}$

Given that arbitral proceedings are akin to legal proceedings in the sense that they culminate in a binding award, the witnesses are under a duty to tell the truth. ${ }^{88}$ In most jurisdictions, there is no legal impediment to taking sworn testimonies in arbitral proceedings, in which case an untruthful witness may be sanctioned under the civil and criminal laws of the seat. Moreover, since it is the tribunal that ultimately needs to be convinced of the claims and counterclaims, it may request any person to give oral evidence which it

${ }^{86}$ KP Berger and O Jensen, Due Process Paranoia and the Procedural Judgment Rule: A Safe Harbour for Procedural Management Decisions by International Arbitrators, (2016) 32 ArbIntl 416; ICC, 'ICC Techniques for Controlling Time and Cost in International Arbitration' (ICC 2018).

87 The IBA Rules are available at: <https://www.ibanet.org/Document/Default.aspx? DocumentUid=60EFAF2E-0308-4005-8244-9CE793B37EA9>. $\quad{ }^{88}$ Art 8(4) IBA Rules. 
considers material to the outcome of the dispute. In this case, however, both parties may also question the witness called by the tribunal. ${ }^{89}$

Apart from fair trial concerns, the lex arbitri in industrialised nations is generally rather relaxed regarding the permissibility of procedural rules dictated by the parties. Sometimes, however, the line is unclear. It is accepted, for example, whether explicitly or implicitly, that applications by the parties for expedited or fast-track arbitral procedures are consistent with the right to fair trial. In contrast, where a tribunal proceeds on the basis of a summary judgment, in which case it chooses not to hear the parties or assess their evidence by weeding out what it perceives to be superfluous (even as per the parties' agreement), it fails to discharge its duty of due process. ${ }^{90}$

\section{CONCLUSION}

If arbitrators are to know one thing about human rights, this is that they form an integral part of the lex arbitri. In jurisdictions that have adopted extensive international human rights obligations, such as those under the ECHR, there is a long line of precedent whereby fair trial guarantees apply to both litigation and arbitral proceedings. It follows that arbitrators must at all times seek advice from arbitral institutions, as well as from the parties themselves, where appropriate, as to the potential human rights implications of the proceedings at hand. Foreign arbitrators will not, and need not, be familiar with the human rights legislation of the seat.

Procedural human rights guarantees may be far-reaching than they had anticipated. Should they fail to comply with the relevant standards, ultimately their award not only risks being annulled by the courts of the seat but may also give rise to liability in tort. Equally, arbitral institutions would do well to train their case managers in fair trial law and prepare detailed instructions to all those engaged in arbitral proceedings, and if in doubt about particular issues to consult an expert at hand within the institution. Clearly, the reputational and financial risk to arbitral institutions and individual arbitrators far outweighs any cost associated with sound legal advice from human rights experts.

Despite the autonomy of international arbitration, both the powers of the tribunal and the applicable law (substantial and procedural) are subject to the mandatory rules of the seat. ${ }^{91}$ Equality in all its dimensions is an integral part of the seat's mandatory rules. Deviations based on consent are permissible, but only where the effect of the deviation does not significantly harm one of the parties. Within this context, both national and international courts and

89 Art 8(5) IBA Rules.

90 TT Landau, 'Claims for Further Particulars or for Summary Dismissal: Are They an Acceptable Practice?' in SR Bond et al., Arbitral Procedure in the Dawn of the New Millennium (Bruylant 2005) 47-55.

91 One of the few scholarly works on this is S Brekoulakis, Public Policy and Mandatory Laws in International Arbitration (Oxford University Press 2019). 
tribunals have had the opportunity to expand on the range and scope of permissible deviations from the equal treatment rule, thereby demonstrating the existence of a transnational judicial dialogue ${ }^{92}$ on this matter. The general principle enunciated in Article 18 of the Model law is manifest in the pronouncements of international tribunals, such as the ECtHR, but also domestic courts, awards by arbitral tribunals (given the absence of extensive annulment proceedings on the ground of non-equal treatment) and the instruments of arbitral institutions worldwide.

92 See RJ Krotoszynski, "I'd Like to Teach the World to Sing (In Perfect Harmony)": International Judicial Dialogue and the Muses - Reflections on the Perils and the Promise of International Judicial Dialogue' (2006) 104 MichLRev 1321; PM Moremen, 'National Court Decisions as State Practice: A Transnational Judicial Dialogue?' (2006) 32 North Carolina Journal of International Law and Commercial Regulation 259. 